\title{
Investigating the Self-Efficacy Beliefs and Experiences of Teachers Teaching Grades 11 and 12 World History without a Textbook
}

\author{
Dorji $S^{1}$, Ramesh Kumar Chettri ${ }^{2}$, Karma Phuntsho ${ }^{3}$, Thukten Jamtso ${ }^{4}$
}

\author{
${ }^{1,2}$ Lecturer in History Education, Samtse College of Education, Samtse, Bhutan \\ ${ }^{3}$ Training Developer, Royal Education Council, Bhutan \\ ${ }^{4}$ Curriculum Developer, Royal Education Council, Bhutan
}

Received: 08 Nov 2020; Received in revised form: 16 Dec 2020; Accepted: 25 Dec 2020; Available online: 30 Dec 2020

(C)2020 The Author(s). Published by Infogain Publication. This is an open access article under the CC BY license

(https://creativecommons.org/licenses/by/4.0/).

\begin{abstract}
In 2017, the Royal Education Council (REC) initiated a paradigm shift in the teaching of world history in grades 11 and 12. This shift was the mode of teaching world history without a prescribed curriculum. This study aimed to investigate the self-efficacy beliefs of teachers teaching world history without a prescribed textbook and also build the knowledge in context to the Bhutanese classroom experience. This research adopted a convergent mixed-method design with social constructivism as a primary research paradigm. Surveys, interviews and document analysis were some of the tools used in this research. Analysis of data highlights academic and professional efficacy levels slightly above average in the 5 point Likert's scale indicating some level of difficulty in teaching without a textbook. The study also shows an insignificant correlation of different professional qualifications on the efficacy level of teachers. This study does not include student views and perspective and limits the conclusion on textbook-less teaching merits and challenges.
\end{abstract}

Keywords - textbook-less, efficacy beliefs, competencies, and opportunities.

\section{CONTEXT OF THE STUDY}

History as a separate subject is taught from grade 7 onwards in the Bhutanese education system. Till grade 6 , it is a part of the social studies subject. Anglo-Indian school curriculum system continued to have influence, especially in the world and Indian history subjects. History curriculum, especially textbooks of world and Indian sections were reviewed less and had no major change and development. This situation impelled the Royal Education Council (REC) to propose the revision of the history curriculum in its $28^{\text {th }}$ Curriculum Board Meeting (CMB).

In 2014, the Ministry of Education (MoE) published Bhutan Education Blueprint 2014-2024 (BEP), a document of education roadmap. This document succinctly outlined the context of the need of revamping education system in Bhutan with clear justifications. Quality of education became a pivotal point of the document and the need for revision of humanities school curriculum especially history and geography were given focus in the document.

Following these developments, in 2013 the REC initiated the history curriculum framework development and series of meetings and conferences were conducted at school, district and national levels to deliberate on the history curriculum. Teachers in schools within the same subject group reviewed their curriculum and submitted the consolidated comments and feedback to respective district education offices. The district office reviewed further in the district level conferences and outcomes were submitted to $\mathrm{MoE}$ and REC. Accordingly, their resolutions were deliberated in the national level curriculum conference themed "Rethinking Curriculum" in 2016. 
The National Curriculum Conference was the first major historical event in the country to discuss, deliberate, and negotiate in revamping the entire school curriculum of Bhutan. There were several outcomes of the National Curriculum Conference- curriculum framework requirement for each subject and thinning the bulky syllabus(Rinzin, 2018). Under the auspices of REC as the institution responsible for curriculum development and review in the Bhutanese education system, the drafting of the curriculum framework to guide history textbook developments were initiated.

In the history curriculum framework development workshop, a historic and far-reaching decision was to go textbook-less in the teaching of the world history in grades 11 and 12. This shift in the approach of teaching world history was surmised on providing a broader scope for learning; creating researchbased learning and enhancing the use of unlimited online materials and documents. It was also reported by Rinzin (2018) that textbook-less teaching provides an opportunity to sharpen students' skill of interpreting world history as they are less dependent on one person's view of history. Further, REC in its notification mentioned that this shift will promote interactive learning, instil and enhance the zeal of exploratory learning, promote critical, analytical, application and interpretation skills in learners(Royal Education Council, 2018). This particular change in world history approach was based on the maturity level of students and considering an opportunity for students to prepare for higher institutions methods of teaching and learning. Students in the higher secondary stage are expected to understand the processes of learning and enhancing their academic horizon with open resources. These, in turn, prepare high school students to adapt better when they are in colleges because, in tertiary institutions, there are no practices of using a prescribed textbook for their courses.

Textbook-less curriculum implementation began in 2017 across all schools in Bhutan. Before the implementation, teachers teaching history in grades 11 and 12 across the schools including private school teachers were oriented in the form of workshops in different regional venues. In these workshops, teachers were given insight on skills to teach without textbook and design lesson activities, assessments, critiquing and using of open online resources.

\section{PROBLEM STATEMENT}

The technical report of REC on Bhutan National School Curriculum Conference (BNSCC) 2016 pointed that history textbooks for higher secondary schools were last reviewed in 2005 and also recorded 523 issues related to the history content (Education, 2016). These notable observations propelled the initiatives to revamp the curriculum of social sciences and humanities. Revamping included the implementation of textbook-less teaching and learning of world history for grades 11 and 12. Textbook-less teaching began in 2017 school academic session and teachers were provided with the world history curriculum framework. In preparing teachers to teach textbook-less world history, a short professional orientation workshop was conducted. With textbook-less curriculum framework and brief familiarization workshop, teachers were expected to design their teaching, learning and assessment. This was a new development and teachers never learned textbook-less teaching pedagogy in their professional training. The national newspaper reported that teachers and students are yet to adapt to the new system owing to poor access to the internet and reference books (Rinzin, 2018) indicating the challenges. It also outlined the rationale of the REC in initiating textbook-less teaching such as to give students ownership to learning, enable history teachers to go beyond a single perspective based textbook and to create interactive learning, among many. Therefore, textbook-less teaching is a paradigm shift from the traditional mode of teaching which was heavily dependent on prescribed textbooks. This demand teachers to be academically and professionally competent, creative, critical and hardworking to make lessons clear for students who are not used to learning textbook-less.

However, there have been no studies done to construct the efficacy level of the implementation of the textbook-less curriculum. Since this is a new shift, it provides scopes for both opportunities and challenges. There is a knowledge gap and preliminary studies are required to build knowledge on this aspect especially in context to Bhutan. More importantly, teachers are experiencing such mode of teaching for the first time and it needs focused study to build. The study results will help the REC and relevant agencies in strengthening teaching and learning world history without a textbook and it can be a baseline study for future researches.

\section{RESEARCH QUESTION}

This paper attempts to delve into the efficacy beliefs of teachers and their efforts to adapt to a new way of teaching 
without a prescribed textbook. This paradigm shift from the textbook-based tradition of teaching and learning in Bhutanese secondary schools is the first policy shift and therefore it seeks to study teachers' experiences and efficacies.

\section{Main Research Question:}

What are the levels of efficacy beliefs and experiences of Bachelors of Education (BEd) and Postgraduate Diploma in Education (PgDE) teachers in the teaching of world history without a textbook?

\subsection{Research Sub-Questions:}

- Does academic and professional qualifications influence the efficacy beliefs of teachers?

- What are the experiences and how have their experiences influenced their teaching of the textbook-less curriculum?

\section{Literature Review}

The literature review is on three thematic areas- self-efficacy beliefs, teaching without textbooks, influences and experiences. This format of the review highlights the focus and relevancy of literature to the subject of study.

\subsection{Self-Efficacy Beliefs}

Teaching is a complex job. It demands efficiency and competence in transferring knowledge and skills in learners. Clark and Bates (2003) state that teaching by nature mandate solving unanticipated, intricate, dynamic and non-linear difficulties. The complexity of teaching indicates the need for teachers to be highly efficacious and competent both academically and professionally.

Self Efficacy Beliefs (SEB) is defined in multiple ways. Bandura and Stajkovic \& Luthans (as cited in Sherab, 2014) defines self-efficacy as individual's belief in his or her capability to organize and execute the course of action required to manage prospective situations; accomplish certain courses of action necessary to function effectually in given circumstances and to Akçali (2017), it is the ability to sway the way people feel, think, behave, and motivate. In teaching, the concept of SEB refers to teachers' competencies to affect the learning outcomes of students including those with low motivation and low ability to learn (Tschannen-Moran et al., 1998). Bray-Clark \& Bates(2003) state that efficacy is largely dependent on the personal agency or how teachers define tasks, employ strategies, view the possibility of success, and ultimately solve the problems and challenges they face. Bandura (cited in Ozder, 2011) opined that teachers with high self-efficacy make more efforts to overcome the problems they face, and they can maintain these efforts longer. Azar
(2010) also corroborated with a similar view that teachers' beliefs of self-efficacy play a role in determining the methods and strategies the teachers use in the classroom resulting in positive affect in students academically. Self-efficacy beliefs have been found to play an important role in student engagement and learning in the classroom((Linnenbrink \& Pintrich, 2003).

The efficacy levels of teachers involved in teaching the textbook-less curriculum demand them to be academically resourceful and professionally competent in their delivery and assessment. Their efficacy levels are expected to impact student learning outcomes.

\subsection{Teaching Without a Textbook}

The dictionary meaning of a textbook is a book of instruction, a book containing facts about a particular subject that is used by people studying that subject. According to Babre (2017), textbooks are written following a given framework of educational standards, be they national or state-based, and outcomes with a particular focus to the flow of the text. The content of these texts is customized to emphasize certain concepts while de-emphasizing or omitting other important concepts of human experience. On the implications of textbooks on student learning, Carpenter, et al. (2006, as cited in Klymkowsky, 2007) said that there is little research on the impact of textbooks on student learning. They also said, many educators see textbooks as valuable assets in their classrooms, others view them as hindrances to the intentional kinds of learning and engagement that account for engaged learning, critical thinking, and community building necessary for students to become informed thinkers(Barbre, 2017). A study by Carpenter et al. (2006, as cited in Klymkowsky, 2007) showed that there is no correlation between textbook purchase and the grade achieved. Further, it is understood that the use of textbooks become obsolete too quickly with discoveries of knowledge and information, it requires constant editions to update to learning needs of students. Because many educators provide detailed online or downloadable notes, it would be a worthwhile exercise to consider whether a textbook is required, or other materials could serve its purpose.

The textbook system is a standard practice in the school system in Bhutan. Limited literature impeded the conclusion on the merits and demerits debate of textbooks and no textbooks in Bhutan. There are no studies done in context to Bhutan on the use and disuse of textbooks. Ruth (2005) states that some textbooks are outstanding and does make discipline excellent and relevant, while some bored and frustrated 
students. They also said textbooks at times insult students' intelligence by making things easier and splitting the subject matter and exploring only limited topics instead of standard content set. They further expressed that without a textbook, teachers can create their curriculum that engages students by relating to their everyday lives. Going textbook-less helps in making lessons clear when the topic is linked to an issue that affects students personally(Ruth, 2005). Teaching without a textbook has pushed teachers to rethink and adapt to changes in the education landscape and forced teachers to unpack standards and think deliberately about what strategies can be used to teach both content and practice standards(Janes, 2017). Teaching without a textbook means more preparation time; means amassing and adapting curriculum from a wide variety of sources including journals, lab books, websites, packed curricula and other teachers (Ruth, 2005). One of the reasons for transforming teaching-learning in the $21^{\text {st }}$ century is the revolution in Information, Communications and Technology (ICT). The internet has unquestionably transformed the way by which information is exchanged, analyzed, and incorporated into our existing knowledge base(Stavrianeas et al., 2008). This textbook-less teaching is geared towards tapping online resources and also in transforming the teaching and learning with technology use.

Literature shows the benefits of teaching without a textbook, but it has also pointed increased teachers' workload negatively impact the delivery of lessons in the class. Teaching without a textbook is a new approach and it requires them to move away from the comfort zones of the textbook because teachers have to scale up their preparation and planning. It demands them to be competent to synthesize, summarize and prepare lessons to test students learning. However, teaching without a textbook can also be an opportunity to enhance their knowledge and skills.

\subsection{Qualification, Experience and Resources}

Literature shows the mixed opinions on the influence of teachers' qualification, experience and availability of resources for teaching and learning. Darling-Hammond (2000), Boots (2007) and Lim-Teo et al. (2007) have expressed that quality teaching is roughly linked to a teacher's content knowledge and has some influences on student achievement. Another study by West et al. (2014) also indicated that the combination of content knowledge and academic coursework seemed to improve teacher effectiveness. Ball et al., (2005) also corroborated that teachers with better content knowledge could reduce the gap in learning especially in urban schools. Similar views are shared by Goldhaber \& Brewer (1996) that teachers who pursue subject-specific degrees or advanced degrees in the subject they taught would enhance their subject matter knowledge and impact student achievement. Walker (2014) concluded that higher the degree of the subject they taught, it would have some positive results in student achievement.

Despite having a significant level of influence of teachers' content knowledge on student achievements the subject matter knowledge is considered to be one of the most contentious issues. Kansanen (2009) shared that knowledge of subject matter would be an irrefutable predictor of quality teaching and interestingly research has shown very little connection between student achievement and subject matter knowledge. The study of Goldhaber \& Brewer (1996) also highlighted that statistically, teacher qualifications did not have significant influence especially with teachers having advanced degrees in English and history. This is a contrast to their general conclusion that teachers pursuing subject related degree would influence their teaching.

Studies have shown that academic content is not the only factor in student achievements. A study done by Cohen et al. (2010) pointed that teaching a course entails more than a superficial knowledge of the subject and Berliner \& Nicholas (2008) opined pedagogy as one of the sensible arts of teaching. Carey et al. (2002) and Usman et al. (2010) have identified the different pedagogical skills that have a positive effect on students' satisfaction: teachers' competency, delivery method, and experience. It is also noted that there is an influence of teachers' experience in their ability to teach (Wenner, 2001) and teachers' preparedness is significantly related to their efficacy level (Pas et al., 2012). In an elementary school level, the study by Alrefaei(2015) reported that teaching experience and education has some impact on teachers' perceptions about their efficacy beliefs, and another study found that teaching experience is positively and significantly associated with teacher effectiveness (Gaotlhobogwe, 2017). The analysis of different studies shows that brand new teachers are less effective than those with some experience(Podolsky et al., 2019).

Resources are very much contextual to countries, schools and institutions. The concept of resources in an educational context is not very conclusive as it comprises anything that aid as an educational means(Gaotlhobogwe, 2017). In the $21^{\text {st }}$ century classroom, ICT is widely used in teaching and learning. ICTs in education can mean the use of technology in communicating, creating, managing, accessing, gathering, and distributing information (UNESCO, 2009). The Internet 
is not just a powerful tool for communication but also arguably the most potent force for learning and innovation (Bush \& Dawson, 2013). However, Chirwa (2018) found poor organization of ICT resources, inaccessibility of internal school network outside the institution are limiting teachers and students' from accessing and using ICTs. He also said that most developing countries lack ICT infrastructures and it is a major obstacle to ICT integration in education. However, teachers in Bhutan are faced with multiple issues and the $\mathrm{MoE}$ has initiated programmes such as pedagogy enhancement and leveraging ICT facilities to build capacities of teachers but it is still a challenge(Sherab, 2014). This challenge of lower technological knowledge may influence the history teachers' efficacy in the teaching and learning of the textbook-less curriculum.

Considering the shift in the teaching from textbook-based to open source, availability of resources, ICT skills and other hindrances, it is expected that teachers' efficacy level in teaching textbook-less would not be highly efficacious. Nevertheless, there is a knowledge gap in understanding the teachers' efficacy levels. Therefore, this study shows the efficacy level of teachers involved in teaching textbook-less curriculum.

\section{METHODOLOGY}

This research employed mixed methods with Creswell's social constructivism as a research paradigm. Social constructivism is concerned with humans and their interaction with the world, and how this results in multiple subjective meanings or understandings(Creswell, 2009). The qualitative method was used in deepening the understanding of quantitative results by analyzing the lived experiences of teachers. This method helped in strengthening the reliability, validity and authenticity of the study as it supplemented and complemented each other in investigating the teachers' selfefficacy beliefs. A purposive sampling strategy was adopted.

A survey questionnaire was shared using a google form to teachers teaching world history without textbooks. The design of the survey instrument adopted a five-point Likert scale: strongly disagree, disagree, neither agree nor disagree, agree and strongly agree on three themes -resources, academic and professional. The survey questionnaire also had four openended questions to allow the respondents to provide additional information. Likert scale is the most widely used approach to scaling responses in survey research to measure attitude, opinions and perceptions. Teachers were contacted through emails and social media app requesting them to participate in the survey and provide their responses to the questions related to the teaching of history textbook-less curriculum. Simultaneously, structured interview questions were emailed to some selected teachers and they were contacted based on certain factors, location, experience and qualification. A total of 10 teachers responded to the email interview. Document analysis of certain notifications from REC and MoE publications were also analyzed.

Basic mean analysis of survey responses was done with the help of Statistical Package for Social Sciences (SPSS). For the qualitative responses, open codes were developed and collapsed to build themes for analysis and to find relationships.

Considering the ethical issues, respondents were given different identity codes such as TID (Teacher Identity) and TR (Teacher Respondent) for respondents to email interviews. All the results and findings are presented in simple tables and graphs along with brief narratives of qualitative findings.

\section{RESPONDENT DEMOGRAPHY}

Through purposive sampling, a total of 125 teachers who are the members of the social media app group 'Textbook-less World History' were contacted through emails and the same app. A total of 62 teachers participated in the survey but 1 respondent was not considered as the respondent submitted the incomplete survey. In the email interview, 10 teachers responded out of 20 teachers who were randomly sampled. The maximum number of respondents in the quantitative survey were from Central Schools (43.3\%) followed by Higher Secondary Schools (35\%) and Private Schools $(37.7 \%)$. The highest number of respondents were teachers with Bachelors of Education (B.Ed) qualification ( $\mathrm{M}=26$; $\mathrm{F}=8$ ).

\section{ANALYSIS AND FINDINGS}

In this section, the results and findings are discussed under different thematic areas- academic efficacy, professional efficacy, qualification influence to teaching and opportunities and challenges in teaching textbook-less curriculum. The efficacy levels were investigated broadly in two areasacademic efficacy and professional efficacy. Besides these efficacies, the study also looked at the academic and professional opportunities and challenges in teaching textbook-less curriculum. 
In the analysis of this study, professional qualifications BEd and $\mathrm{PgCE} / \mathrm{PgDE}$ are considered academic qualifications. In Bhutan, there is a difference in the entry level to these professional development training institutes. For the BEd, the entry requirement is grade 12 , while for $\mathrm{PgCE} / \mathrm{PgDE}$, the entry-level is a Bachelor's degree in the subject of their choice. There were respondents with no professional qualification and the valid percent was less than 10. Their means are not included in the analysis and findings.

\subsection{Academic Efficacy Beliefs of Teachers}

The new school history curriculum is categorized into four major strands (themes). Textbook-less world history curriculum for grades 11 and 12 follows the same themes as other grades such as Historiography, Evolving Civilization, Governance and Peace and Identity, Spirituality and Culture. The survey items covered only the strands or themes, not on the content details under each theme or strand.

The quantitative data show that teachers are slightly efficacious irrespective of different academic and professional training and qualifications. The qualitative analysis indicates some academic and professional difficulties in their efficacy, however, it also highlights the opportunities for academic and professional developments in teachers. The findings are discussed below.

The average mean score of all academic efficacy items of teachers which were calculated manually from the means is 3.88 out of 5 point rating of Likert scale with a mean standard deviation of 0.234 .

In the mean comparison of academic efficacy levels of teachers with BEd and Postgrad in education qualifications, results show no distinct variations in their academic competencies or efficacies. Both categories of teachers are equally efficacious in the teaching of the textbook-less curriculum. However, the efficacy level of historiography strand is slightly above the average (2.5) for both qualifications as compared to other academic efficacy items. The qualitative analysis provides the reasons for slightly less efficacy as lack of prior knowledge and for having not studied the content, limited conceptual understandings of some topics, being unable to synthesize historiography philosophies, difficult theories, and lack of resources. Although, not much as historiography, evolving civilization strand was also found challenging too. This was reasoned as difficulty in explaining the biological terms and concepts and biological evolution theories which are content of evolving civilization strand.

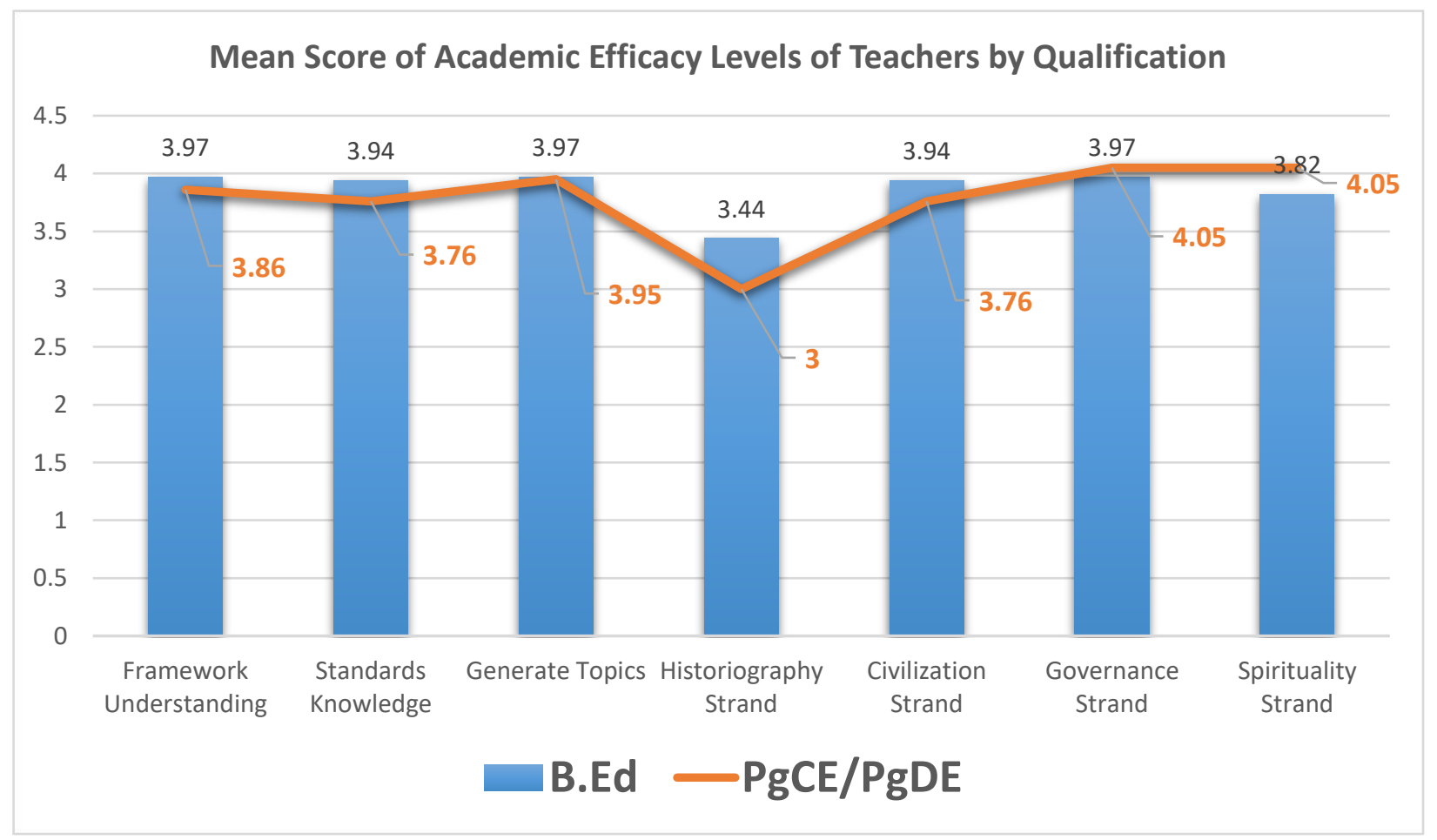

Fig.1: B.Ed. Academic Efficacy Levels and. PgCE/PgDE Academic Efficacy Levels 


\subsection{Professional Efficacy Beliefs of Teachers}

The professional efficacy beliefs statements were on their ability to access online resources, critic the resources, synthesize information, design learning activities, innovate strategies, assess student works and design overall lesson well. These are the key competencies required in teaching textbook-less curriculum.

Data analysis show the insignificant difference in the professional efficacy beliefs between the two professional qualifications- BEd and Postgrad. The mean range for B.Ed is between 3.35 and 4.03, while for postgrads it is 3.67 and 4.0. Teachers with B.Ed qualification are slightly efficacious in designing lessons while Postgrad teachers are little efficacious in innovating teaching strategies. Except for BEd teachers with a mean score of 3.35 in critically analyze the online resources or information, most of the mean scores are close to 4 (agree) level. This indicates that both the group of teachers are efficacious in the professional area.

Although the professional efficacy beliefs are similar to academic efficacy, the qualitative data points certain professional difficulties. Some of the challenges faced were their inability to decide how much and how little to include information in each topic, filter the vastly available information, synthesize and provide, definite information. Teachers also expressed their difficulty in teaching textbookless on being not used to in teaching depending on objectives and to draw topics. If these minor challenges are taken care, the mean score of professional efficacies might likely improve.

Table 1. Professional Efficacy B. Eds. and Postgrads.3.81

\begin{tabular}{|c|l|c|c|}
\hline \multicolumn{3}{|c|}{ Professional Efficacies Mean Scores (5-Point Likert's Scale) } & \multicolumn{1}{|c|}{ Statement } \\
\hline Sl.No. & \multicolumn{1}{|c|}{ BEd } & Postgrads \\
\hline 1 & I can access online information accurately for textbook-less teaching and learning & 3.98 & 3.81 \\
\hline 2 & I can critically analyze the information to be used for textbook-less teaching & 3.35 & 3.67 \\
\hline 3 & I can synthesize the information for textbook-less teaching & 3.56 & 3.67 \\
\hline 4 & I can design student learning activities in textbook-less teaching & 3.82 & 3.67 \\
\hline 5 & I can innovate teaching and learning strategies for textbook-less teaching & 3.94 & 4 \\
\hline 6 & I can design different assessments in textbook-less teaching and learning & 3.85 & 3.81 \\
\hline 7 & I can design textbook-less lessons well & 4.03 & 3.95 \\
\hline
\end{tabular}

\subsection{Influence of Academic Qualification on Teaching Textbook-less Curriculum}

The qualitative interview studied teachers' opinion on the influence of academic qualifications on their teaching of the textbook-less curriculum. Teachers with BEd qualification are with grade 12 qualification but undergo intensive three to four years of content and professional training in the two colleges of education in Bhutan. Though there is no quantifiable evidence, most respondents expressed that there would certainly be some impacts of academic degree in history in textbook-less teaching and learning. However, their concern of comfortability in historiography and evolving civilization strands support their belief of academic influence. This is also supported by the quantitative mean score of 3.33 (BEd) and 3 (Postgrads) in historiography strand which is slightly lower compared to other academic efficacy items. Participants shared that certain concepts and theories relating to biological evolutions and others as reasons for their beliefs on academic influence. They attribute their lower efficacy beliefs to lack of prior knowledge and not having studied before as most of these topics were not part of their academic and professional courses. They also stated that it is also due to their inability to synthesize different philosophical theories of historiography and lack of resources.

Participants justified that academic qualification is exposure to information, learning the right content knowledge and diverse ideas. Having the right knowledge helps their lessons become easier in class. Textbook-less curriculum required them to have a lot of knowledge and also be open-minded. They feel that such knowledge and experience is gained at a higher level of studies. The impact is well expressed by one respondent, "academic qualification has impacts in teaching textbook-less curriculum because to teach the textbook-less curriculum, one has to be competent in doing research, 
analyzing historical facts and comprehending the matter of history".

\subsection{Influence of Professional Qualification}

Teaching textbook-less curriculum requires professional competencies such as designing a lesson, developing different assessment types, use of ICT to harness online information, synthesize information, and basic research and inquiry skill. Majority of respondents agreed that professional qualification will impact the teaching of the textbook-less curriculum. The analysis pointed out that teachers confronted various professional difficulties- the inability to decide the right content, authenticate online sources, apply history skills, finding the best strategies to teach and to assess students textbook-less works. Respondents also stated that professional qualification did impact their textbook-less teaching and learning.

Participants highlighted that higher degrees give a lot of experience to handle the curriculum, and prepare them to be more efficient and organized. Teachers viewed that professional studies aid them in giving the right content knowledge, building competency in teaching skills and strategies and also in identifying reliable websites. One of the respondents shared, professional degree "is a must factor in teaching textbook-less curriculum". Another teacher corroborates, “...... looking for the right information to meet the learning object is difficult when I am not sure what kind of information I should be looking for.'

\subsection{Experiences, Opportunities and Challenges}

Teachers had varying experiences in the teaching of the textbook-less curriculum. There are both challenges and opportunities. These opportunities and challenges are discussed as experiences of teachers. Teachers faced minor challenges like lack of financial support for project-related excursions, both hard and electronic resources and other soft materials for textbook-less curriculum. Teachers also mentioned the absence of dedicated room to be used as a history lab, museum and classroom could influence their teaching. The total mean of all these issues is around 2.5 in 5 point scale but there was some statistically not significant variation in the standard deviations. The qualitative data corroborates that teachers did not get the required resources and has impacted their lesson planning, delivery and discussion in textbook-less teaching and learning. School libraries lacked resources or reference books were limited in numbers especially for new themes introduced in the school curriculum like historiography strand. Participants pointed inadequate or dysfunctional computers in schools and lack of reliable or slow internet connectivity as some of the factors that influenced textbook-less teaching and learning.

These factors contributed to making lessons more teacher centred, took a lot of time to prepare for class and slowed the teaching learning process. Respondent TR9 concluded, "lack of resources has always been a challenge in imparting my lessons. It has sometimes shaken my competence in my subject".

Although teaching without prescribed textbook gave teachers some levels of difficulty, this change in the teaching and learning of world history for grades 11 and 12 gave opportunities or scopes for development of both academic and professional efficacies. Teachers found that there is a lot of scope for self-learning, developing critical thinking and building and assessing student centred learning. Textbookless teaching helped them in broadening their knowledge horizon and disseminating the most current information. Teachers also shared they could explore different reading materials and design new pedagogies. One of the highlights of finding is that the formative assessment is more applicable in the textbook-less curriculum. One of the respondents concluded, "that textbook-less curriculum encouraged exploratory learning; inculcated research culture, encouraged independent learning and removed restrictions in learning". 
Table 2: Significance correlation of textbook-less teaching and competency development

\begin{tabular}{|c|c|c|c|c|}
\hline & & $\begin{array}{l}\text { Textbook-less } \\
\text { better provided } \\
\text { opportunities rearning } \\
\text { prescribed textbooks }\end{array}$ & $\mid \begin{array}{l}\text { I gained a lot of } \\
\text { knowledge teaching } \\
\text { without a textbook }\end{array}$ & $\begin{array}{l}\text { I became competent } \\
\text { in pedagogy and } \\
\text { critical assessment of } \\
\text { student works }\end{array}$ \\
\hline $\begin{array}{l}\text { Textbook-less provided } \\
\text { better learning opportunities } \\
\text { than prescribed textbooks }\end{array}$ & $\begin{array}{l}\text { Pearson } \\
\text { Correlation } \\
\text { Sig. (2-tailed) } \\
\text { N }\end{array}$ & $\begin{array}{l}1 \\
61\end{array}$ & $\begin{array}{c}.567^{* *} \\
.000 \\
61\end{array}$ & $\begin{array}{c}.241 \\
.062 \\
61\end{array}$ \\
\hline $\begin{array}{l}\text { I gained a lot of knowledge } \\
\text { teaching without a textbook }\end{array}$ & $\begin{array}{l}\text { Pearson } \\
\text { Correlation } \\
\text { Sig. (2-tailed) } \\
\mathrm{N}\end{array}$ & $\begin{array}{c}.567^{* *} \\
.000 \\
61\end{array}$ & 61 & $\begin{array}{c}.398^{* *} \\
.001 \\
61\end{array}$ \\
\hline $\begin{array}{l}\text { I became competent in } \\
\text { pedagogy and critical } \\
\text { assessment of student works }\end{array}$ & $\begin{array}{l}\text { Pearson } \\
\text { Correlation } \\
\text { Sig. (2-tailed) } \\
\text { N }\end{array}$ & $\begin{array}{c}.241 \\
.062 \\
61\end{array}$ & $\begin{array}{c}.398^{* *} \\
.001 \\
61\end{array}$ & 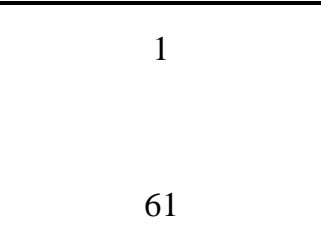 \\
\hline
\end{tabular}

**. Correlation is significant at the 0.01 level (2-tailed).

In Pearson's correlation analysis on the opportunities and gaining knowledge it showed a significant correlation (Pearson's $=.567^{* *}$; significance $=.000$ ). There is also linear correlation significance between gaining knowledge and becoming competent in pedagogy and critical assessment of student works (Pearson's $=.398$; significance $=.001$ ) at the 2tailed coefficient significant value at 0.01 . This correlation indicates that teachers had significant opportunity to gain knowledge teaching textbook-less curriculum and as a result, they became competent in pedagogy and critical assessments of student works.

\section{DISCUSSIONS}

The study revealed that teachers are slightly efficacious both academically and professionally irrespective of their academic and professional qualifications, however, there are challenges in handling textbook-less curriculum. In enhancing their efficacy, teachers have organized their innate talents and learned skills (Bandura, n.d.) and have organized their knowledge and skills to accomplish certain courses of action necessary to function effectually in given circumstances (Sherab, 2014). Mean efficacy scores (academic $=3.828 \&$ professional=3.792) show the considerable effort of teachers to be efficacious despite the challenges and it supports the views of Bray-Clark \& Bates (2003) that efficacy of teachers also depends on the personal agency, or how a teacher defines the task, employ strategies, view the possibility of success, and ultimately solve the problems and challenges they face. This is also noteworthy because teachers have had no formal training in teaching textbook-less curriculum, except for a 5day workshop on general introduction of the textbook-less curriculum framework, its objectives and basic lesson preparation.

Though studies done by Darling-Hammond (2000) and LimTeo et al. (2007) showed that quality teaching is linked to a teacher's content knowledge and the strong relationship with student achievement but this study showed that academic qualification does not make any difference because the efficacy level of BEd and Postgrad teachers were similar and did not show any significant difference in the mean scores of each item. The study supports Goldhaber \& Brewer (1996) where qualifications do not matter and especially teachers with advanced degrees in English and history did not have a statistically significant impact on student achievement. Although the study did not consider the students' performance 
to indicate the efficacy level, the grade 12 common board examination results show improvement in the students' performance in history compared to past old history curriculum examination results.

Nevertheless, Goldhaber \& Brewer (1996) stated contradictory statement that teachers who pursue subjectspecific degrees or advanced degrees in the subject they taught would enhance their subject matter knowledge and can positively impact student achievement. A similar finding was shown by Walker (2014) that higher qualification in the subject they taught would positively influence student achievements. But the limitation in the literature on a similar subject and more importantly in Bhutanese context has been a gap in concluding the impact of academic and professional qualifications in student achievements. The study also revealed that academic and professional degree means exposure to information, learning the right content knowledge, and diverse ideas. Teachers also expressed that right knowledge influences their lessons.

This study revealed practical difficulties which also impeded efficacy in their lessons. Lessons became more of teacher centred taking a lot of time to prepare for class and slowed the teaching learning process as it needed more effort from teachers in referring to vast sources. A similar view was shared by Ruth (2005) that teaching without a textbook means more preparation time; means amassing and adapting curriculum from a wide variety of sources including journals, lab books, websites, packed curricula and other teachers.

Resources and technological facilities have contributed to achieving a higher efficacy rate of teachers. Textbook-less teaching required immense dependence on readily available resources and online sources. The internet became an indispensable source of knowledge and information just as Bush \& Dawson

(2013)who recognized the internet as one of the most potent forces in learning and innovation. The potency of internet and facilities is also highlighted by Chirwa (2018) and absence of ICT resources and inaccessibility of internal school network outside the institution limited teachers and students' from accessing and using ICTs for their teaching and learning. Similarly, this study showed that history teachers and students lacked access to computer facilities and reliable internet connectivity.

Although, there were difficulties in handling textbook-less curriculum, nevertheless, it also gave certain opportunities to teachers to develop their efficacy both academically and professionally. Teachers mentioned of their cognitive development particularly their critical thinking skills, widening of academic knowledge, of keeping abreast to current affairs and learning to design rubrics. One respondent concluded, "textbook-less teaching encouraged exploratory learning; inculcated research culture, encouraged independent learning, removed restrictions in learning".

\section{CONCLUSION}

This study examined the efficacy beliefs of teachers teaching grades 11 and 12 world history without prescribed textbooks and the conclusions were drawn based on the findings. One of the conclusions and recommendations is that in the initial stages of the paradigm shifts in teaching and learning, it is important to provide refresher courses to teachers on certain topics deemed hard and were not part of their academic and teacher preparation times. Pedagogical and assessment practices to be incorporated are to be provided as professional development courses for the increased efficacy of teachers. Resources both hard and soft becomes indispensable in the textbook-less teaching and relevant institutions are required to support schools in this area. The Internet has been a major player in the success and efficacy of textbook-less teaching and such facilities need to be revamped and strengthened for the achievement of goals. In this study, only teachers who have taught and currently teaching were included. One of the limitations so this study was the exclusion of students and their performances.

\section{REFERENCES}

[1] Akçali, A. A. (2017). Turkish Pre-Service History Teachers' Self-Efficacy Beliefs and Motivations on the Teaching Profession. Universal Journal of Educational Research, 5(4), 648-663.

[2] Alrefaei, N. A. (2015). Teachers' Sense of Efficacy: Examining the Relationship of Teacher Efficacy and Student Achievement. Theses and Dissertations, 111.

[3] Azar, A. (2010). In-service and pre-service secondary science teachers' self-efficacy beliefs about science teaching. Educational Research and Reviews, 5(4), 175-188.

[4] Babre, J. (2017). The Anti-Textbook Proposal: Reconceiving History Education without Textbooks Journal of Education \& Social Policy Vol. 4, No. 4; December 201756346 Tom Raper Hall 2325 Chester Blvd Indiana University East Richmond, IN 47374 United States of America-Google Search. (n.d.). Retrieved September 25, 2020

[5] Bandura, A. (n.d.). SOCIAL COGNITIVE THEORY. 85. 
[6] Barbre, J. (2017). The Anti-Textbook Proposal: Reconceiving History Education Without Textbooks. Journal of Education \& Social Policy, 4(4), 56-62.

[7] Berliner, D. C., \& Nicholas, S. L. (2008). Collateral damage: How high stakes testing corrupts America's schools. Cambridge, MA: Harvard Education Publishing Group.

[8] Boots, J. (2007). Student achievement and passport to teaching certification in mathematics.

[9] Bray-Clark, N., \& Bates, R. (2003). Self-Efficacy Beliefs and Teacher Effectiveness: Implications for Professional Development. XXVI(1), 10.

[10] Bush, J., \& Dawson, R. (2013). Internet Brings Historic Shift in Learning. Miami Herald.

[11] Carey, K., Cambiano, R. L., \& De Vore, J. B. (2002). Student to faculty satisfaction at a midwestern university in the United States.

[12] Chirwa, M. (2018). Access and use of internet in teaching and learning at two selected teachers' colleges in Tanzania. International Journal of Education and Development Using ICT, 14(2).

[13] Cohen, A., Porath, M., \& Bai, H. (2010). Exceptional Educators: Investigating Dimensions of their Practice. 4(2), 14.

[14] Creswell, J. (2009). Research Design: Qualitative, Quantitative, and Mixed-Method Approaches.

[15] Darling-Hammond, L. (2000, Spring). Teacher Quality and Student Achievement: A Review of State Policy Evidence. ResearchGate.

https://www.researchgate.net/publication/240273279_Teacher _Quality_and_Student_Achievement_A_Review_of_State_P olicy_Evidence

[16] Education, R. E. (2016). Complete Bhutan National School Curriculum Conference 2016 Report. ResearchGate. https://www.researchgate.net/publication/326736255_Comple te_Bhutan_National_School_Curriculum_Conference_2016_ Report

[17] Gaotlhobogwe, M. (2017). The impact of lack of resources on declining students' enrolments in Design and Technology in Botswana junior secondary schools. Design and Technology Education: An International Journal, 17(1).

[18] Goldhaber, D. D., \& Brewer, D. J. (1996). Evaluating the Effect of Teacher Degree Level on Educational Performance. https://eric.ed.gov/?id=ED406400

[19] Janes, B. (2017, February 14). Lessons Learned after Teaching without a Textbook. Achieve the Core Aligned Materials. https://achievethecore.org/aligned/lessons-learned-afterteaching-without-a-textbook/

[20] Kansanen, P. (2009). Subject-matter didactics as a central knowledge base for teachers, or should it be called pedagogical content knowledge? Pedagogy, Culture \& Society, 17(1), 2939. https://doi.org/10.1080/14681360902742845

[21] Klymkowsky, M. W. (2007). Teaching without a Textbook: Strategies to Focus Learning on Fundamental Concepts and
Scientific Process. CBE—Life Sciences Education, 6(3), 190193. https://doi.org/10.1187/cbe.07-06-0038

[22] Lim-Teo, S. K., Chua, K. G., Cheang, W. K., \& Yeo, J. K. (2007). The Development of Diploma in Education Student Teachers' Mathematics Pedagogical Content Knowledge. International Journal of Science and Mathematics Education, 5(2), 237-261. https://doi.org/10.1007/s10763-006-9056-5

[23] Linnenbrink, E. A., \& Pintrich, P. R. (2003). The Role of SelfEfficacy Beliefs Instudent Engagement and Learning Intheclassroom. Reading \& Writing Quarterly, 19(2), 119137. https://doi.org/10.1080/10573560308223

[24] Ozder, H. (2011). Self-Efficacy Beliefs of Novice Teachers and Their Performance in the Classroom. Australian Journal of Teacher Education, 36(5), 1-15.

[25] Pas, E. T., Bradshaw, C. P., \& Hershfeldt, P. A. (2012). Teacher-and school-level predictors of teacher efficacy and burnout: Identifying potential areas for support. Journal of School Psychology, 50(1), 129-145.

[26] Podolsky, A., Kini, T., \& Darling-Hammond, L. (2019). Does teaching experience increase teacher effectiveness? A review of US research. Journal of Professional Capital and Community, 4(4), 286-308. https://doi.org/10.1108/JPCC-122018-0032

[27] Rinzin, C. Y. (2018, Winter). Teaching World History without textbook yet to pick up - KuenselOnline. Www.Kuenselonline.Com. https://kuenselonline.com/teaching-world-history-withouttextbook-yet-to-pick-up/

[28] Royal Education Council. (2018). Circulars. Royal Education Council. https://rec.gov.bt/circulars/

[29] Ruth, G. (2005, February 8). No Books, No Problem: Teaching Without a Text. Edutopia. https://www.edutopia.org/teachingwithout-text

[30] Sherab, K. (2014). Gross National Happiness Education in Bhutanese Schools: Understanding the Experiences and Efficacy Beliefs of Principals and Teachers. https://rune.une.edu.au/web/handle/1959.11/16997

[31] Stavrianeas, S., Stewart, M., \& Harmer, P. (2008). Beyond the printed page: Physiology education without a textbook? Advances in Physiology Education, 32(1), 76-80. https://doi.org/10.1152/advan.00031.2007

[32] Tschannen-Moran, M., Hoy, A. W., \& Hoy, W. K. (1998). Teacher Efficacy: Its Meaning and Measure. Review of Educational Research, 68(2), 202-248. https://doi.org/10.3102/00346543068002202

[33] UNESCO. (2009). Guide to Measuring Information and Communication Technologies iEducation. Institute for Statistics, Montreal.

[34] Usman, A., Danish, R. Q., \& Malik, M. E. (2010). The Impact of Service Quality on Students' Satisfaction in Higher Education Institutes of Punjab. Journal of Management Research, 2(2). https://doi.org/10.5296/jmr.v2i2.418 
International Journal of English Literature and Social Sciences, 5(6)

Nov-Dec 2020 / Available online: https://ijels.com/

[35] Walker, D. J. (2014). The Impact of Highly Qualified Teachers on Students' Academic Achievement and Graduation Rates. UMD Theses and Dissertations. https://doi.org/10.13016/M2R629

[36] Wenner, G. (2001). Science and mathematics efficacy beliefs held by practicing and prospective teachers: A 5-year perspective.

[37] West, P. E., Lunenburg, F. C., \& Hines, M. T. (2014). Teacher Quality Variables and Efficacy for Teaching Minority Students. Education Leadership Review of Doctoral Research, 1(1), 39-57. 